\title{
ルイ 7 世による初期ゴシック大聖堂建設への関与の実態について A STUDY ON THE ACTUAL RELATIONSHIP BETWEEN LOUIS VII AND THE CONSTRUCTIONS OF THE EARLY GOTHIC CATHEDRALS
}

\author{
加藤 耕 一* \\ Koichi KATO
}

\begin{abstract}
The constructions of most of the early gothic cathedrals were started under the reign of Louis VII. This paper investigates the actual relationship between Louis VII and the construction of the cathedrals.

Regarding the finances of the constructions, Louis VII gave economic aid in some case, but they weren't the great patronages. As for his power of ruling over the "royal bishopric", it reduced under his reign. Thus, Louis VII wasn't the great patron of the early gothic style. The fact that the king renounced his right to deprive the bishops' possessions might help the construction of the gothic cathedrals.
\end{abstract}

Keywords : Early Gothic Style, France, Capetian Dynasty, Saint-Denis, Louis VII, Royal Bishopric 初期ゴシック様式、フランス、カペー王朝、サンニドニ、ルイ 7 世、王立司教座

\section{1. 序}

ゴシック様式とその社会的背景 ${ }^{1)}$ 、思想的背景の関係性を指摘し た先行研究は数多い。本稿は、なかでもサンニド二大修道院との関 連でしばしば指摘される、フランス王権と初期ゴシック様式の関係 性を再考察しようとするものである。

初期ゴシック期（1144-1194 年2)）において、フランス国王の 直轄地はイルニド=フランスおよびその周辺に限定されていた。 の地方にはサン・ドニを筆頭に初期ゴシック様式のモニュメントが 多数存在し、ゆえにゴシック様式はイルニド=フランスで誕生した といわれる。2つの饾域が重なり合っていることから、先行研究で は直接・間接を問わず、フランス王権とゴシック様式の関係性が示 唆されてきた ${ }^{3)}$ 。初期ゴシック様式が誕生した地域とフランス王家 の直轄地とは、ともに〈イルニド=フランス〉と呼ばれるが、ここ で言われる〈イルニド=フランス〉の概念が示す領域は㖟昧であ り、実際には王の直轄地が極めて限定された狭い地域であるのに対 し(地図 1 参照)、初期ゴシック大聖堂が建設された都市は、王領 の周辺地域にまで広がっている。しかしながら「最初のゴシックは イルニド=フランスという一つの限られた領域一より正確にいえ ばカペー君主の領土一一と驚くほど同一視される4)」とする言説が 存在するほどに、両者の領域的な類似は、実際にはその境界線を同
一にしているわけではないにも拘わらず、初期ゴシック様式とフラ ンス王権の漠とした慗がりを示唆し䌇けるのである。

地理的な平行関係を示すことによって漠然と両者の磐がりを示唆 するにとどまらず、本穓では、王領で誕生したことが初期ゴシック

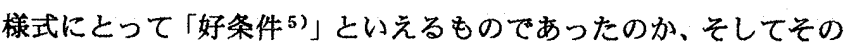
ことは「国王芸術 ${ }^{6}$ 」としてゴシック様式の性質を決定づけるもの であったのか、などの点を明らかにしたい。すなわち両者の関係性 の実態を再検証し明らかにすることが、本稿の目的であるて。

\section{2. ルイ 7 世と初期コシック様式}

ゴシック様式の誕生とフランス王権との関わりを考える上でもっ とも重要な国王は、ルイ 7 世（在位 : 1137-80 年) である。初期 ゴシック大聖堂と呼ばれる大聖堂は、ほとんどすべてがルイ 7 世の 治世に着工され主要部分の建設が進められている8)。

ルイ 7 世は先王ルイ 6 世の次男であり、4葴年上の兄フィリップ の存命中はパリ司教座学校において聖職者になるべく教育を受けて いた9)。しかしフィリップが急逝したため、急㠊若いルイが世継ぎ の王太子として呼び戻され、兄の死の 6 年後には、父王の死により 即位することになる10)。

若年期に聖職者としての教育を受けた彼の素恙、さらに 1147 年

\footnotetext{
本稿は，2000年度大会学術講演会で発表した「カペー王朝と12世紀初期ゴシック」をもとに，大幅に加筆・修正したものである。

* 東京大学大学院工学系研究科建築学専攻 Research Student, Department of Architecture, Graduate School of Engineering, 研究生. 博士 (工学) 
の第二次十字軍への参加、また神聖ローマ皇帝フリードリッヒ・バ ルバロッサとの確執により亡命したローマ教皇アレクサンドル 3 世 や、イギリス王ヘンリー2世との確執により亡命したカンタベリー 大司教トマス・ベケットという二人の高位聖職者を相次いでフラン スに受け入れたことなどから11、ルイ 7 世はきわめて信仰の篤い国 王として知られている。このことは、彼を大聖堂建設と結びつける 状況証拠的な役割を果たしているといえよう。

ルイ 7 世の領土については以下の点が重要である。すなわちルイ 7 世は1137年、アリエノール・ダキテーヌとの婚姻により、旧来 のカペー王家の直轄領であるイルニド=フランスに加えて広大なア キテーヌ公領をも支配することになった。ところが1152年のアリ エノールとの離婚、さらにアリエノールのノルマンティー公アンリ 2 世との再婚により、フランスの国土の大半はこのノルマンディー 公一彼は1154年イギリス王ヘンリー 2 世として即位した一一の 支配下に置かれ、対照的にルイ 7 世の領土は再びイル =ド=フラン ス周辺の僅かな領地に限られることとなったといら点である。フラ ンス王権とゴシック様式の発生の関連を指摘する論は、主としてこ の限られた王領周辺に初期ゴシック大聖堂が多く見られることを諭 掬としている。しかしながらイルニド=フランスは王領としてフラ ンス国内で特別な地位にあったわけではなく12)、むしろ領士の限定 は王権の零落を示しているに過ぎないと考えることができる ${ }^{13)}$

これに対して王権とゴシック様式の誕生を結びつけた多くの論が 説得力を持ち得たのは、ゴシック様式誕生の教会堂といわれるサン =ド二大修道院が〈王家の墓所〉としての特別な意味を持った修道 院であったという共通慧識のためと考えられる。O・ジムソンはこ の認識をより一層強化するために、サンニドニ大修道院長シュジエ がルイ 7 世の父王ルイ 6 世の治世に、如何にして王国内でのサン= ドニの地位を高めたかを詳細に論じた ${ }^{14)} 。$ ル 6 世の下でサン=ド 二大修道院はフランスにおける宗教的な中心となり、カペー王家と サンニドニとはそれまで以上に密接な関係で結ばれたという。

H・ゼーデルマイヤが王権とゴシックとの関係性を論じたとき も、その主たる論拠はサン＝ドニがフランス国王の墓教会堂であっ たということであった。彼によれば、シュジェはゴシック様式を

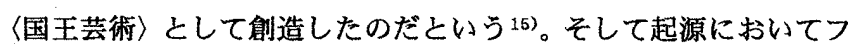
ランス国王と緊密に融合していたゴシック大聖堂が、王領の拡大と ともに広く伝播したという点において、「フランス王権と大聖堂と

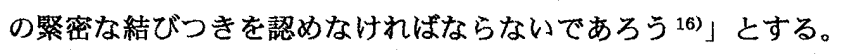

しかしながら、王権とゴシック様式の関係性についてもっとも踏 み込んだ議論をしたといえる上記二人の議論でさえ、サン＝ドニ及 びその後の初期ゴシック大聖堂の建設が実質的に進められたルイ 7 世の治世については、ほとんど言及していない。そこで以下、第 3 ・ 4 節ではこれについて具体的な検証をすることとする。第 3 節では 主として金銭的援助を中心とする、ルイ 7 世による大聖堂建設への 援助の有無、第 4 節ではルイ 7 世と王立司教座 ${ }^{17)}$ の関係性の実熊 について検証する。

\section{3.ルイ7世による大量堂建款への経済援助}

まず検討すべきは、ゴシック様式誕生の教会堂といわれるサン= ドニ大修道院に関してであろう。大修道院長シュジェはルイ 6 世の 治世には国王の碩問として信頼も篤く政務に追われていたため、サ ンニドニ大修道院のナルテックスの建設はルイ 6 世が没した 1137
年に開始された ${ }^{18)}$ 。さらに 1140 年から内陣の建設が始められ、 1144年に献堂式が執り行われている。すなわちシュジェはルイ 7 世の即位から 7 年間でサンニドニ大修道院の建設を進めたのであ る。彼が国王の掑政として再び国政の表舞台に立ったのは、ルイ7 世が十字軍に出発した 1147 年以降であった。その後 1151 年に没 するまで、特に王国内の教会に関連する問題の多くはシュジェが責 任を持って解決したことが知られる19)。サンニド二大修道院の建設 期間に当たる 1137 - 1144年にシュジェがまったく国政に参加し ていないということはないようであるが、政治に対する責任が比較 的軽堿されていた時期に、シュジェがサン＝ドニ大修道院の建設に 精力を傾けていたと考えることができよう。

ここで具体的に、大聖堂建設費用の問題について考える。シュ ジェは『献堂録』の中で、「修道士たちの会議において、出席者た ちの助言とわが君主たる国王の承認により、この事業を完成させる ために [大修道院の]年収を充てることを決定した ${ }^{20)} 」$ と説明して いる。具体的には、「祭㐭亡聖遺物への寄進に奇り集まった 150 リーヴル—うち 100 リーヴルは市21) が立つとき、50リーヴルは 聖ドニの祝祭において集まった一一と、それに加えてボース地方の ヴィレーヌと呼ばれる所領からの収益のうち50 リーヴル、合計

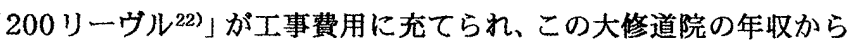
の工事費用の捻出がすべての工事が終了するまで続けられた。

ここでシュジェか゚「君主たる国王の承認（domini regis assensu）」 により、大修道院の年収から200リーヴルを工事費用に充てるこ とを决定したと説明しながら、国王からの資金援助にはまったく言 及しないことから、ルイ 7 世からの大聖堂建設工事への特別な資金 援助は存在しなかったと結論づけられる。他方 13 世紀前半 (1231 年頃)には、ブランシュ・ド・カスティーユと聖王ルイ（ルイ 9 世、 在位: 1226-70 年) が、サンニドニの新しい身廊の建設に対し、 450,000 リーヴルもの寄付をしているのが知られる ${ }^{23) 。 シ ュ シ ゙ エ ~}$ が内陣を建設するのに必要としたと考えられる年額 200 リーウル と比較したとき、インフレともいゔべきこの驚くべき金額は俄には 参考としがたいが、聖王ルイの下で多額の奇付が存在したのは明ら かであり、13世紀のサンニドニ建設を聖王ルイによる国家的プロ ジェクトと位置づけることは可能であろう24)。これに対して 12 世 紀のサンニドニ建設については、親子二代にわたる国王ルイとシュ ジエの緊密な結びつきにも拘わらず、この事業に対する国王からの 金銭援助が存在しなかったことが注目に值する。

サンニドニ以外の初期ゴシック大聖堂で、ルイ 7 世との結びつき がしばしば指摘されるのはサンリス大聖堂である。1155年頃、ル イ 7 世洅建工事の始められたサンリス大聖堂に関して、王国内の 大司教、司教といった高位聖職者たちに宛てて、その工事費用への 奇付を募る開封栜書を発効した ${ }^{25)}$ 。国王の使者がこの栜書を携えて 王国内を回り、王の名の下に寄付を徽収したものと考えられる。ル

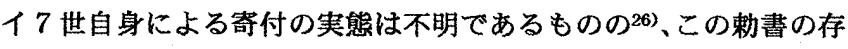
在はフランス国王の大蟹堂建設に対する積極的な協力姿勢を示す重 要な証拠となる。しかしながらルイ 7 世が他の大聖堂について同様 の勅書を発効した事例は知られておらず27、国王による斯様な大聖 堂建設の保護政策が一般的に行われていたとは考えられない。

ルイ 7 世が実際に大聖堂建設に奇付したことが明確な寒例として は、パリ大聖堂の建設に対する奇付が挙げられる。これは 1180 年 
になされたもので、この時ルイ 7 世は 200 リーヴルを䓫付したこ とが知られる ${ }^{28)}$ ここの額は約 40 年前にサン二ド二大修道院の建設 工事において、シュジエが一年間に必要とした額と同じであり、か なり高額の奇付であったといえよう29)。しかしながらパリ大聖堂の 建設を指揮した可教モーリス・ド・シュリーは1196年、その死に 際して遗産から100リーヴルを寄付したことが知られている30)。 たラン大聖堂の建設においても、建設を指揮したラン司教ゴーティ エ・ド・モルターニュは1174年、やはり遗産から 100 リーウル、 さらに生前はおそらく20 年ほどにわたって毎年 20 リーウルを寄 付していたことが知られており ${ }^{31)}$ 、その寄付の総額において国王の パリへの奇付額を上回ったことは確実である。これら二人の司教が 遺贈した 100 リーヴル、また約 50 年後にルイ 9 世がサン＝ドニに 奇付した 450,000リーヴルと比較したとき、ルイ 7 世が奇付した 200リーヴルはあまりに見劣りするといわざるを得ない。

上述の寒例以外で、ルイ 7 世が初期ゴシック大聖堂の建設工事に 関連して何らかの金銭的援助をした実例は知られていない322。した がってルイ 7 世が初期ゴシック大聖堂のパトロンとして、これを積 極的に援助したと考えることはできまい。ここでは、大聖堂建設協 力の名目での寄付・援助だけを考えた。それ以外の名目での司教座 への奇付が存在する場合もあるが、それは国王との司教との政治的 な関係といえる。仮にその奇付が大聖堂建設に援用されたとして も、それ注司教側が都合よく利用したに過ぎない。ルイ 7 世の大聖 堂建設への積極的な姿勢に限定するならば、パリとサンリスに見ら れた例外的な協力姿勢が存在したのみと結論づけられよう。

\section{4.ルイ 7 世と王立司教座}

前節で見たように、ルイ 7 世が初期ゴシック大照堂の建設を積極 的に援助した実例はごく僅かである。それにも拘わらず、カペー王 権と初期ゴシックの密接な慗がりを論じた先行研究が、強い説得力 を持ち得た要因としては、ジムソンが述べた次のような見解があっ たと考えられる。

「フランス王国は、…中略‥「王立の」司教区としてフランス王冠に従 属したいくつかの大きな司教管区に取り巻かれていた。れら 6 人の統 治者一ランスの大司教、ランとラングルとシャロンとポーウェとノワ イヨンの各司教——は国国の公や伯であり、この資格において大きな封 建諸侯であり、彼らの領地をあわせると王領の大きさをはるかに淩ぐも のであった。他のすべての封建墥侯と同じく「王立」司教区の占有者た ちは国王の封臣として忠誠を暂った。しかも教会関係の封土は世襄制で はなかったので、それらの司较を任命する王の権限は彼の権力を大いに 增大させた ${ }^{33)}$ 。」

ゼーデルマイヤもまた、まったく同様に初期ゴシック大聖堂建設 の背景として王立司教座の存在を強調している34)。本節ではまず、 王立司教座の実態とその歴史的背景を概観し、さらにルイ 7 世之王 立司教座の関係が如何なるものであったかを検証することとする。

王立司教座について考光る上では、ルイ 7 世が即位した半世紀ほ ど前の、ローマ教皇グレゴリウス 7 世（在位 : 1073-85 年）によ るグレゴリウス改革が無視できない。これは世俗権力による司教座 支配に対抗した叙任権闘争として知られ、特に俗人による司教叙任 が結果として巻き起こす聖職売買を強く批判したものであった。グ レゴリウス改革は 1122 年のウォルムス協約により終結し、その
後、国王による司教座支配のあり方は変容していく。それ以前に世 俗権力、すなわち中央の国王、地方の諸侯が司救座に対して有して いた権限は、主として(1)空位教会収入取得権、(2)聖職者遗産没収 権、(3)新司教選任権の3つである。(1)は司教の空位期間中に世俗権 力が行使する徵税権や教会保護権であり、(2)司教の遺した動産の 領有権、(3)は新司教の選出、聖別、叙任の権限であった ${ }^{35) 。 ~}$

グレゴリウス改革以後、可教座の有する諸権限は教権と俗権とに 区別され、フランス国王はローマ教皇の教権（spirituralia）に抵触 する(3)の司教叙任については放率する一方で、俗権 (temporalia)に 関する(1)、(2)の支配を強化したと考えられている。すなわち上記 (1)、(2)を中心亡する俗権が国王に策属する権限 (レガリア) として 整備され、選举で選出された新司教に国王がレガリアを委僙するシ ステムを構築したのである ${ }^{36)}$ 。新司教の選出に当たっては、俗権の 授与椎を根拠に、国王は選挙民たちに選挙の許可を与光 ${ }^{37) 、 ま た そ ~}$ の選出者を確認し、彼を叙任する許可を与えることができた ${ }^{38) 。 ~}$

叙任権闕争の前後では司救座支配のあり方は少なからず変化した が、いずれにせよ何らかのかたちで司教座は世俗権力に従属してい た。グレゴリウス改革以前から、カペー王権の影響が及ばない地方 都市においては、同様の支配が世俗諸侯によっても行われていたの である ${ }^{39}$ 。特に世俗諸侯との関係では、明確な司教所領を形成する ことのできた北フランスの一部の例外 ${ }^{40)}$ を除いて、その教会領地 が世俗権力により横領、強㤪、没収されることも頻繁に起こってい た ${ }^{41)}$ 。他方、主としてイルニドニフランス周辺には国王に支配され

地図 1 : ルイ 7 世治世末年（1180 年）のフランス (部分)

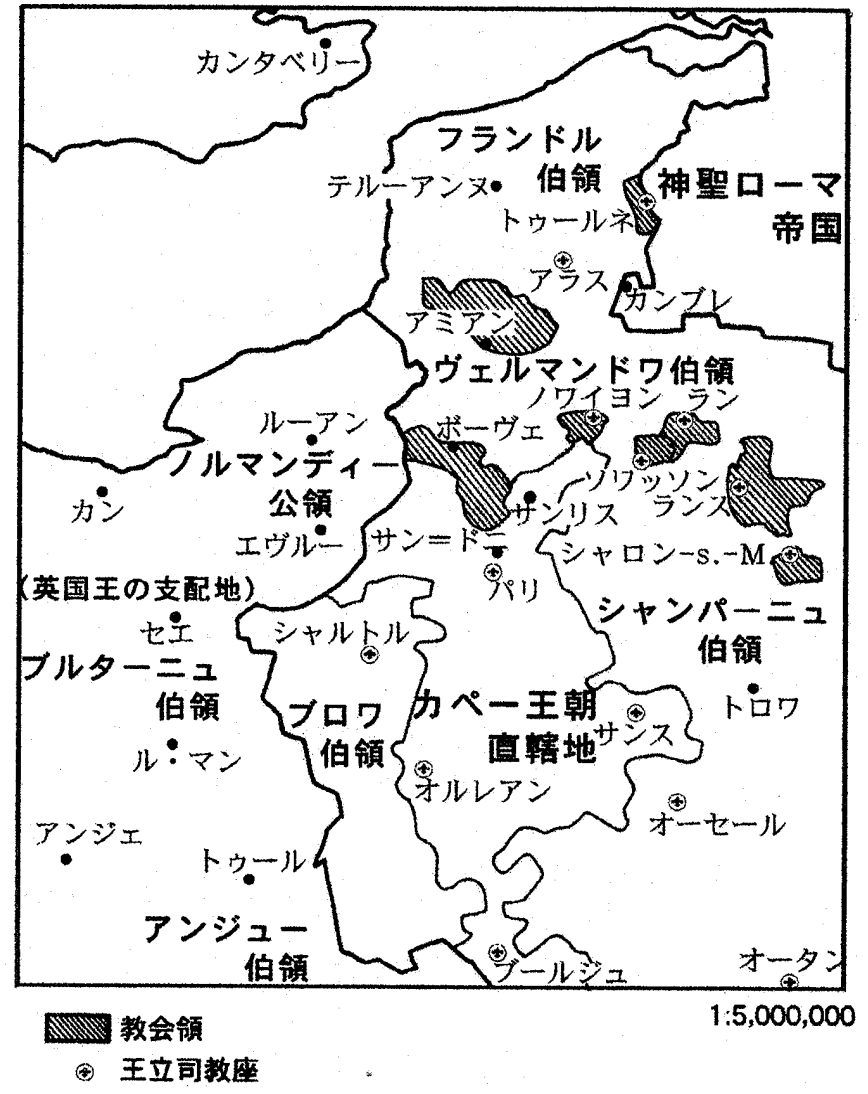

渡辺節夫『フランス中世の政治権力棈造の研究れ、p. 557

M. Pacaut, Louis VII et les élections épiscopales dans le royaume de France. を基に筆者作成。 
た司教座が多く存在し、それらが〈王立司教座〉と呼ばれる。グレ ゴリウス改革以後はレガリアとは本来国王にのみ帰属する権限であ るとする考えが浸透し、世俗諸侯らによる司教座支配にとっては不 利な状沿が生まれることとなった42)。

ここで注意しなければならないのは、王立司教座とは、国王が当 該司教座に対して何らかの書状などを付与して認定するような類の ものではないということである。ある司教座が空位になったとき、 そこで国王がレガリアの権利を行使したことが判明したとき、その 司教座は便宜的に王立司教座と呼ばれる。したがって王立司教坐で あるか否かの判定は司教座のレガリアに関する史料の有無に左右さ れ、研究者によってもその判定が異なる場合がある43)。すなわち前 述の、空位教会収入取得権、聖職者遺産没収権、あるいは新選出司 教に対する認否権などを、国王が行使したことを示す史料が存在し た司教座についてのみ、それは王立司教座と判定されるのである。

$\mathrm{W} \cdot$ 二ューマンによれば44、ユーグ・カペーの治世からルイ7世 の治世に至るまで一貫して王立司教座を維持したのは、パリ、サン ス、ノワイヨン、ラン、ランスの 5 司教座であり、また、この間ル イ 6 世の治世においてのみ王の支配から脱したのはシャルトル、オ ルレアン、ソワッソン、モーの 4 司教座である。その他、初期ゴシッ ク大聖堂の建設された町としては、サンリスはルイ 6 世、ルイ 7 世 の治世に国王の支配から脱し、またアラスは逆にルイ 6 世、ルイ 7 世の治世に王立司教座となっている ${ }^{45)}$ 。また、上記以外で長期にわ たって王立司教座だった司教座としては、ユーグ・カペーの治世を 除いて王立司教座であったオーセールと、フィリップ 1 世の治世を 除いて王立司教座であったル・ピュイが举げられる。

ここれらの司教座都市を概観すると、カペ一朝初期からルイ 7 世に 至るまで長期間にわたって王の支配下にあった司教座と初期ゴシッ ク大聖堂が建設された都市とは、よく一致している。さらに王立司 教座の総数は、ルイ 6 世統治下の 9 からルイ 7 世統治下の 18 へと 倍増する (表 1 )。このデータだけを見れば、ルイ 7 世の治世にお ける王権の司教座に対する影響力の増大が想定され、このことと初 期ゴシック様式の繁栄とを結びつけることができるように思われ る。だが表 1 の如く長いスパンで見たとき、王立司教座の総数はル イ 6 世の治世を除いてほぼ横選いである。すなわちこのことは、グ レゴリウス改革の直中であったルイ 6 世の治世にのみ司教座に対す る介入が減ったものの、その後、前述のようなレガリアの整備によ り、再びルイ 7 世の治世では司教座との連携関係が生じたと考える べきであろう。ルイ 6 世とルイ 7 世の治世だけを比較して、これが 司教座に対する影響力の増大を示していると断言するのは難しいと いえる。

さらに、別のデータも存在する。国王の集会に列席した司教の数 を調べたE・ブルナゼルによれば46)、ルイ 6 世の治世からルイ 7 世
の治世にかけて、参席司教の延へ人数は 107 人から 27 人へと激㳦 するのである。また、延べ人数ではなく、出席司教の所属する司教 座の数で比較しても、24司教座から 14 司教座へと 10 減少してい る。ルイ 6 世の治世中には参席したがルイ 7 世の治世には一度も参 席しなかった 10 の司教座には、サンリス、ラン、アミアン、ボー ヴェなどが含まれる。旧フランキア（イルニド=フランス周辺）の 司教が各王の治世中に一度も参席しなかった事例はルイ 6 世の治世 までは皆無であったといい、司教層を重要なメンバーとする聖俗諸 侯の合議に依拠したフランス国王の統治形態が变貿し始めた様子が うかがえる47)。王の集会からの司教層の離脱僋向を見ても、ルイ7 世統治下における司教座に対する国王の影響力の增大を想定するの は難しいといえよう48)

さらに、ルイ7世統治下の司教座という大きな括りではなく、各 司教座の司教個人とルイ 7 世の関係を細見したい。表 2 の 6 司教座 49) ではサンリス以外が王立司教座と考えられているが、それ以外 の 5 司教座についても司教交代の都度、ルイ 7 世がレガリアの権利 を行使しているわけではない。文献史料から明らかになっている限 りでは、表の如く、国王によるレガリアの権利の行使（表、々印） はごく僅かである。さらにこの限られた事例についても、これを大 聖堂着工年代とあわせて見ると、ラン、アラス、パリの司教座に対 して王のレガリアが行使されたのは、大聖堂再建工事の着工以前で あり、工事に着手した司教の就任時には国王の介入はなかったこと がわかる。また王の集会への司教の参席状況（表、下線）を大聖堂 着工後に限って見ると、ノワイヨシ司教ボードワンが 1150 年に、 パリ司教モーリスが 1169 年にぞれぞれ 1 回ずつ、サンス大司教 ユーグが 1153-55 年に計 4 回参席しているか゚、これに対しサンリ ス、ラン、アラス司教は大聖堂着工後に一度も王の集会に出席して いないことがわかる。

「教会関係の封土は世襲制ではなかったので、それらの司教を任 命する王の権限は彼の権力を大いに增大させた均」ことがゴシック 大聖堂の建設に結びつくものであったならぱ、大聖堂の建設を始め 推進した司教とルイ 7 世との密接な関係が見られてしかるべきであ ろう。しかしながら以上の検討によれば、少数の司教を除いてルイ 7 世との慗がりは見られない。そればかりか、むしろルイ 7 世によ る司教座支配は軟化傾向にあったのではないかと考えられる。とい うのは、レガリアの重要な権利の一つである聖職者遺産没収権につ いて、ルイ 7 世はしばしばこれを放萧しているのである（表、※ 印)。アリエノールとの結婚によりアキテーヌ公の称号を得たルイ 7 世怆、同 1137 年、ボルドー大司教管区に属する司教座に対して 当該司教座が遺産没収権の行使から免除されることを約束した。同 様にパリ（1143年）、シャロン=シュルニマルヌ (1147 年)、サン ス (1156 年、部分的に)、ラン (1158 年)、ブールジュ (1159 年)

表 1 : 王立司教座の総数および、王の集会への参席数

\begin{tabular}{|c|c|c|c|c|c|}
\hline & $\begin{array}{l}\text { Robert II } \\
(996-1031)\end{array}$ & $\begin{array}{l}\text { Henri I'r } \\
(1031-1060)\end{array}$ & $\begin{array}{l}\text { Philippe } I^{\text {er }} \\
(1060-1108)\end{array}$ & $\begin{array}{l}\text { Louis VI } \\
(1080-1137)\end{array}$ & $\begin{array}{l}\text { Louis VII } \\
(1137-1180)\end{array}$ \\
\hline 王立司教座 ${ }^{*}$ & 19 & 16 & 17 & 9 & 18 \\
\hline 参席数 & $22($ 延べ 73) ** & $22($ 延べ 62) ** & $27($ 延べ 161) ** & $24\left(\right.$ 延べ 107) ${ }^{* * *}$ & $14\left(\right.$ 延べ 27) ${ }^{* * *}$ \\
\hline \multicolumn{6}{|c|}{ * $\quad$ W.M. Newman, Le domaine noyale sous les premiers Capétiens(987-1180), p. 216.} \\
\hline \multicolumn{6}{|c|}{ J.-F. Lemarignier, Le gouvernement noyal aux premiers temps capetiens (987-1108), Paris, 1965, pp. 202-203. } \\
\hline E. Bor & \multicolumn{5}{|c|}{ E. Bournazel, Le gouvemement capétien au XIF' sizcle : $1108-1180$, pp. 189-190. } \\
\hline
\end{tabular}


表 2 : 初期コシック時代の司教たち

\begin{tabular}{|c|c|}
\hline $\begin{array}{l}\text { サンス(क) } \\
(1140 \text { 年以前) }\end{array}$ & $\begin{array}{l}\text { Henri (1122-42), Hugues (1142*1 } \\
(1153,54,55,55)\end{array}$ \\
\hline $\begin{array}{l}\text { ノワイヨン(ぬ) } \\
(1147-48 \text { 年比) }\end{array}$ & $\underset{(1140)}{\operatorname{Simon}}(1123-48),{ }^{\star 2}$ Baudouin II (1148-67), Baudouin III (1167-74), Rainald (1175-88) \\
\hline $\begin{array}{l}\text { サンリス } \\
(1153 \text { 年頃) }\end{array}$ & Pierre I (1134-51), Thibaut (1151-54), Amaury (1156-67), Henri (1168-85) \\
\hline $\begin{array}{l}\text { ラン(な) } \\
(1155 \text { 年煩) }\end{array}$ & Barthélemy (1113-51), ${ }^{\star 3}$ Gautier I (1151-55), Gautier II (1155*2 -74), Roger (1174-1207) \\
\hline $\begin{array}{l}\text { アラス(ホ) } \\
(1160 \text { 年頃) }\end{array}$ & $\begin{array}{l}\text { Alvise } \\
(1140)\end{array}$ \\
\hline $\begin{array}{l}\text { パリ(4) } \\
(1160 / 63 \text { 年頃) }\end{array}$ & Etienne $(1124-42), \underset{(1153)}{\not 5}$ Thibaut $\left(1144^{* 3}-58\right)$, Pierre Lombard $(1158-59), \underset{(1169)}{\text { Maurice }}(1160-96)$ \\
\hline
\end{tabular}

*印はルイ 7 世治世中、王立司教座であったことを示す。（）内は推定着工年代。特に初期ゴシックに関係する司教座のみ を採り上げた。ただし、ソワッソン大聖堂についてはルイ 7 世の治世中に建設された部分のうち現存するのは南袖廊だけ であることから除外した。またカンブレ大聖堂は神聖ローマ帝国項内に存在したため、これも除外した。国王の集会に出 席した司教には下線を引き、その年代を示した。

参考: M. Pacaut, Louis VII et les elections épiscopales dans le royaume de France, pp. 54, 66-67, 149-54 ; W. M. Newman, Le domaine royale sous les premiers Capétiens (987-1180), pp. 216-223 ; E. Bournazel, Le gouvemement capétien au XII siècle : 1108-1180, pp. 189-190.

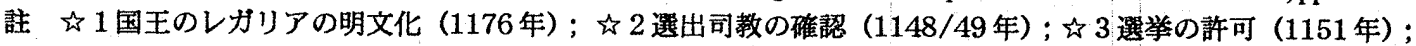
江 4 選出司教の碓認 (1149/50 年); 污 5 選举への同意 (1143/44 年)

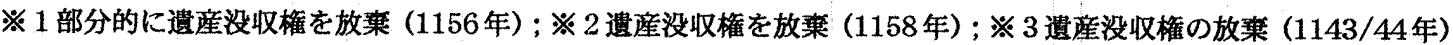

の各司教座について、ルイ 7 世は遺産没収権の行使からの免除を約 束している51)。前述の如く、パリ司教モーリス・ド・シュリーとラ ン司教ゴーティエ・ド・モルターニュはともに、その遗産を大聖堂 建設費用のために奇付したことが知られている。ルイ 7 世自身が、 果たして大聖堂建設に役立てるために遺産没収権を放萧したかどう かは不明であるが、ラン・パリの両司教による遺産からの建設費用 寄付はルイ 7 世による遗産没叹権の放萧がなければなしえなかった ことである。したがって、ルイ 7 世の意図は不明であるものの、む しろ王権による司教座支配が弱まったことが、ゴシック大聖堂の建 設には有利に鹳いたと結論づけられる。

\section{5. 結}

以上の如く、初期ゴシックの司教座の多くとルイ 7 世とは王立司 教座というかたちで関倸を持っている場合が多かった。しかしなが らその一方で、ルイ 7 世が大聖堂建設に金銭的な援助をした実例は 少なく、また王立司教座と国王との関倸性もむしろ希薄なもので あったと考えられる。13世紀の聖王ルイの治世にパリがゴシック 様式の中心となり、王権がゴシック様式の摧護者となったとする $\mathrm{R}$ ・ブランナーの指摘があるが52)、これを 12 世紀のルイ 7 世と初 期ゴシックの関係にまで拡大解粕することはできないであろう。む しろ遣産没収権の放菓に顕著に見れる、ルイ 7 世による司教座支配 の軟化傾向により司教の有する諸権限が強化されたことが、結果的 に大聖堂建設に結びついたと結論づけられる。

註

1) コシック様式と社会背景の関係性の指摍は、少なくともウィオレ=ルニ デュクにまで邀る。VIOLLET-LE-DUC, E. E., Dictionnaire raisone de l'architecture française du XIe au XVIe siecle, t. II, reimpression, Paris, 1967, p. 281. 112 世紀末から 13 世紀初頭に建てられた大聖堂は、どこに見られ るであろうか。それはノワイヨン、ソワッソン、ラン、ランス、アミア ンなどの町であり、それらはすへて、最初にコミューン運動の綘火を上 げたところであった。それはまたイルニド=フランスの首都パリであ り、君主権力の゙中心であった。それはまたルーアンであり、フィリップ・ オーギュストが煘選したもっとも美しい地方の中心であった。」
2) H・フォションP西欧の芸術 2 コシック (上)』神沢・加藤・長谷川・ 高田訳、鹿島出版会（SD選書）、1978 年、p. $80 ; \mathrm{H} \cdot$ ゼーデルマイ ヤ『大聖堂の生成』前川道朗・黒岩俊介訳、中央公論美術出版、1995 年、 p. 55。

3) $\mathrm{H} ・ フ$ フション、前揭書、pp. 4-9, 16 ; E・ランベール「コシック美 街过任保子訳、美布出版社、1965年、pp. 30-43;STODDARD, Whitney S., Art and Architecture in Medieval France, Icon Editions, 1972, p. 93. な巳゙

4）○・フォン・ジムソン『ゴシクの大聖堂』前川道郎訳、みすず書房、 1985 年、 p. 54 。

5) H・フォション、前揭蓄、p. 16 。

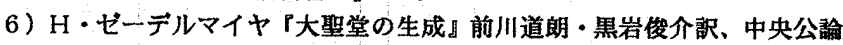
美術出版、1995年、p. 414 。

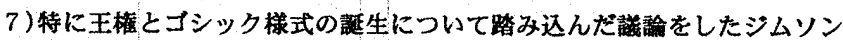
の前揞書と、ゼーデルマイヤの前揭書が、本稿の主たる再㭲証の対象で ある。

8) 本稿では初期ゴシック大聖堂として、サンス大辢堂 (1140 年以前)・ノ ワイヨン大聖堂 (ca. 1147-48)・カンブレ大盟堂 (ca. 1150)・サンリ ス大聖堂 (ca. 1153)・ラン大聖堂 (ca. 1155)・アラス大聖堂 (ca. 1160)・パリ大旺堂 (ca. 1163)・ソワッソン大聖堂 (南袖蓈、ca. 1177) を想定している (カッコ内蛙着工年代)。このうちサンス大聖堂は、着 エがルイ 6 世の治世であった可能性がある。

9) SASSIER, Yves., Louis VII, Fayard, 1991, pp. 15-16. レジーヌ・ペルヌー 『王妃アリエノール・ダキテーヌ』福本秀子訳、パピルス、1996年、p. 23 によれば、サン・ド二大聖堂附属学校において。

10) SASSIER, Y, op.cit., pp. 60-61.

11)このことは純粋な信仰心によるというよりは、2人の政治的ライウァル に対抗する意図があったとも孝えられる。DUBY Georges, France in the Middle Ages 987-1460, trans. J. Vale, Basil Blackwell Ltd., 1994, p. 185.

12）フランス王はイルニド=フランス地方に对して、単なる一諸侯として接 していた面もある。渡边節夫 アフランス中世政治権力構造の研究』東京 大学出版、1992 年、p. 345。

13）コ・ボニによれば、アリエノールとの結㛭がカペー王領に安定をもたら

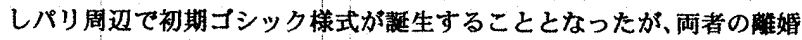
後、1150 年代からは新棣式の中心が王国の北と北東の境界及びその外 惻の南フランドルから南シャンパー二ュに連なる工業・商業都书へと移 動したという。BONY, Jean, French Gothic Architecture of the 12th and 13th Centuries, Berkeley, 1983, p. 119.

14） ○・フォン・ジムソン、前揭書、pp. 62-67。

15） H・ゼーデルマイヤ、前揭書、p. 414。

16) 前揭書、 p. 420 。

17）ルイ 7 世と初期ゴシックの結ぴつきについて、ぜーデルマイヤとジムソ ンが共通して主張するのは、初期コシック大聖堂の多くが王立司教座で 
建設されたということである。ゼーデルマイヤによれば、王立司教座の 数はルイ 7 世に至るまで增加し、大聖堂の思想がそれらの司教阵を通し て伝播したという（H・ゼーデルマイヤ、前揭書、p. 422）。またジム ソンによれば、教会関係の封土は世䘫制ではなかったので、王立司教座 における国王の司教任命権により、国王の権力が增大したという（） フォン・ジムソン、前揭書、pp. 58-59)。本稿では、ルイ7世と王立 司教座の慗がりに着目したこの二人の先行研究を中心的な検討の対像と し、これについて特に第 4 節で詳論することとする。

18）ジムソン、前揭書、pp. 81-83。

19) BOURNAZEL, Eric, "Suger and the Capetians", P. L. Gerson(ed.), Abbot Suger and Saint-Denis, New York, 1986, p. 59.

20) PANOFSKY, Erwin, Abbot Suger on the Abbey Church of Saint-Denis and Its Art Treasures, Princeton Univ. Press, 2nd ed., 1979, pp. 102-103.

21）この〈市 (Indicto)〉は、サンニド二大修道院の保護の下に開かれた定期 市であり、重要な収入源の一つであった。1109 年、ルイ6世はこれに 対抗して、パリとサンニドニの中間に別の〈市〉を設監した。これによっ てサンニト゚ニの〈市〉の収入は減少することになったが、シュジェの要 請に従って1124年、ルイ 6 世はその管轄権をサン＝ド二大修道院に鿁 渡したといら（○・フォン・ジムソン、前揭書、pp. 68-69)。これは ルイ 7 世ではなく、その先王の時代の出来事であるが、抢そらく早い時 期から大修道院の改築を計画していたシュジェにとって、フランス王の 妥㗎は大修道院の建設費用に大きな道を開くことになったであろう。

22) PANOFSKY, op. cit., pp. 102-103.

23) FORMIGE, Jules, L'abbeye royale de Saint-Denis, Paris : Presse Universitaire de France, 1960, p. 107.

24） R・ブランナーによれば、13 世紀半ばのフランスはその繁栄の頂点に あり、望王ルイは十字軍のために年䫫 250,000 リーヴル、王室運営のた めに50,000リーヴルを費やすことが可能であったという。BRANNER, Robert, St. Louis and the Court Style in Gothic Architecture, London : Zewmmer, 1965, p. 3.

25) LUCHAIRE, Achille., Etude sur les actes de Louis VII, Bruxelles, 1964, no363 ; MORTET, V. et DESCHAMPS, P., Recueil de textes relatifs a l'histoire de l'architecture, Paris : CTHS, 1995, pp. 731-732.

26） M・オベールは1168年にルイ 7 世による笴付があったとするが史料な どは示されておらず、詳細怯不明である。AUBERT, Marcel, Senlis, petites monographies des grands edifices de la France, Paris : Henri Laurens, 1930, p. 21.

27) A・リュシェールが編簧したルイ 7 世の発行した栜書集成 (LUCHAIRE, A., op. cit.) には、サンリス（no. 363）以外に、大聖堂建設のための寄 付に関するものは存在しない。

28) KRAUS, Henry, A prix d'or. Le financement des cathedrales, Paris : Cerf, 1991, p. 34.

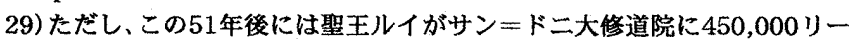
ヴルを笴付したことを考光ると、200リーヴルの価值が連続的に低下し ている可能性もある。

30) MORTET et DESCHAMPS, op.cit., p. 750.

31) B. M. Laon : ms. 341 : fo 133.

32）ルイ 7 世の発行した勅書（LUCHAIRE, A.,op.cit.) の中には、サンリス への笴付を募る栜書が見られるのみである。むろんパリの実例のように 栜書として発行されず、聖堂参事会の史料に笴付の事実が記されている 可能性もあるが、註 8 で举诊たこれ以外の初期ゴシック大聖堂に関する いくつかの主要先行研究でも、その実例は知られていない。サンス： HENRIET, J., "La cathEdrale Saint-Étienne de Sens, Bulletin monumental, t.CXL, 1982, pp.81-174.; SEVERENS, K. W. , "The early Campaign at Sens, 1140-1145", J.S.A.H., vol. XXIX, 1970, pp.97-107./ノワイヨン:LEFÈVREPONTALIS, E., "Noyon", Congrès Archeologique de France, t. LXXII, 1905, pp.170-190.; SEYMOUR, C., Jr., Notre-Dame of Noyon in the 12th Century, Yale U. P., 1939. / ラン : BOUXIN, A., La cathedrale Notre-Dame de Laon, Laon, 1890.; CLARK, W.W. and KING, R., Laon Cathedral, London, 1983-7. /アラ ス:HÉLIOT, P., "Les anciennes cathédrales d'Arras", Bulletin de la Commision royle des monuments et des sites, t. IV, 1953, pp.7-109.; LE BOLAY, E. et DUCLOS, M. L., Notre-Dame-en-Cité d'Arras, Arras, 1999. /ソワッソン : LEFÈVRE-PONTALIS, Eugène, "Cathedrale de Soissons", Congrès Archeologique de France, t. LXXVIII, 1911, pp.318-337.; SANDRON, D., La cathedrale de Soissons : architecture du pouvoir, Picard, 1998. なご。

33）汭ムソン、前揭書、pp. 58-59。

34）ゼーデルマイヤ、前揭書、p. 422 。 35）渡边節夫、前揭書、p. 148 。

36）前揭書、pp. 145-149。特に、p. 147 を参照。「フランスで王が司教座 を「新司教に与える (dare episcopatum)」といら表現が各種文書から姿 を消し、代わって「レガリアを委誐する（regalia dimittere, concedere)」 という表現が一般化するのはルイVII 以降である。」

37）例えば 1151 年、ランの聖堂参事会員たちは、ルイ 7 世による選挙の許 可を得るためにシュジエに書簡を送っている。NEWMAN, William M., Le domaine royale sous les premiers Capétiens (987-1180), Paris : Sirey, p. 222.

38）渡辺節夫、前揭書、p. 149 。

39）前揭書、p. 148 。

40) ランス、ラン、ノワイヨン、シャロン=シュル＝マルヌなど

41）渡辺節夫、前揭畫、p. 307 。

42）前揭書、p. 149 。

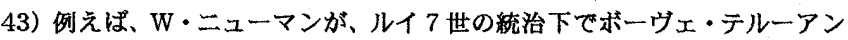
ヌ・アミアン・サンリスが王立司教座でなかったと判断したのに対し、 M・パコはこれら 4 司教座が王立であったと主張している。PACAUT, Marcel, Louis VII et les Elections Épiscopales dans le royaume de France, Paris : J. Vrin, 19, p. 67.

44) NEWMAN, W. M., op.cit., p. 216.

45）M・パコによれば、サンリスもルイ 7 世の下で王立司教座である (PACAUT, M., op. cit., p. 67.)。アラスは 6 世紀後半からカンブレ司教座 に従属し、司教座は空位になっており、再び司教座が置かれたのが1093 年のことであるので、ルイ 6 世以前に王立司教座であることを示す史料 が存在しないのは当然のことである (HELIOT, Pierre, “Les anciennes cathedrales d'Arras", p. 13)。

46) BOURNAZEL, Eric, Le gouvernement capétien au XII siècle : 1108-1180, Limoges : Presses universitaires de France, 1975, pp. 189-190.

47）渡辺節夫、前揭書、p. 143 。

48）本稿、註 17 参照。

49）表 2 て除外したカンブレは、神聖ローマ帝国に属すためフランス国王と の関係は存在しない。しかしカンブレ司教区はランス大司教管区に属 し、また 1144 年のサンニド二内陣の献堂式にカンブレ司教は出席して いた。フランス国王との関係ではなく教会組織としての慗がりを見たと き、カンブレは初期ゴシックの他の大聖堂と、密接な聚がりを持ってい るのである。

50） ジムソン、前揭書、pp. 58-59。

51) PACAUT, M., op. cit., p. 31.

52） R・ブランナーによれば、パリがゴシックの形態にもっとも影㮩を及ぼ す唯一の源泉となったのは 1240 年以降である。BRANNER, Robert, op.cit., p. 112.

（2001年 7 月 10 日原稿受理，2002年 1 月 10 日採用決定） 